\title{
The Readiness of Educational Competency in Higher Education in Connecting the Era of Industrial Revolution 4.0
}

\author{
Rismawati Br Sitepu ${ }^{1,3^{*}}$, Anis Eliyana ${ }^{1}$, Ali Raza $^{1,2}$, and Marfianita Rosalina ${ }^{3}$ \\ ${ }^{1}$ Faculty of Economics and Business, Airlangga University, Jl. Airlangga No.4, \\ Surabaya 60286, Indonesia. \\ ${ }^{2}$ Government College University Faisalabad, Kotwali Rd, Gurunanakpura, Faisalabad, \\ Punjab 38000, Pakistan \\ ${ }^{3}$ STIE Mahardhika Surabaya, Jl. Wisata Menanggal No.42A, Surabaya 60234, Indonesia.
}

\begin{abstract}
Universities within the era of the 4.0 industrial revolution, now must immediately improve in preparing themselves, especially related to human resources. Lecturers as a determining factor in the progress of education, are always required to upgrade their skills and abilities. In Indonesia, the majority of lecturers are dominated by baby boomers and generation $\mathrm{X}$ or digital immigrants who, in some cases, experience obstacles. In the present reality that students are now a millennial or digital native generation who tend to have their learning styles and patterns. This article highlights the competencies that must be mastered by lecturers in the current industrial revolution 4.0 era, namely: (i) educational competence, (ii) competence in research, (iii) competence of technological commercialization, (iv) competence in future strategies, (v) competence counsellor, (vi) competence in globalization, and vii) joint competence.
\end{abstract}

Keywords: Education competency, human resource, industrial innovation, lecturer competence, research advancement.

\section{Introduction}

Topics discussed factually that is now rampant in scientific forums in both the fields of education, politics, and economics is the presence of the fourth generation of the revolutionary era, which is more familiar with the industrial revolution called 4.0 or abbreviated IR4.

The history of the industrial revolution began at the end of the 18th century, which was marked by the emergence of a variety of equipment supported by water vapor engines. These times were referred to as the era of industrial revolution 1.0. The wave of change took place again in the late 19th century, which was called the era of industrial revolution 2.0. At this time, significant changes were seen in the industrial world which

\footnotetext{
*Corresponding author: rismawati.sitepu-2019@ feb.unair.ac.id
} 
changed with the presence of factories based on electricity. The pace of change continued in the 20th century with the presence of the 3.0 industrial revolution marked by the use of electronic technology used in the production process in factories. In this era, there was much reduction in labour or labour because the use of human labour had been drastically reduced. The existence of human power has been displaced by the presence of electronically controlled machine tools to produce more production quantities. This condition certainly benefits the company because there is no need to spend more on production costs for overtime wages of its employees. Will become a blessing when countries and communities can prepare carefully to take the opportunity and ability to innovate creative industries. Moreover, able to increase productivity and efficiency in the modern production process while providing convenience and comfort for consumers.

What is the connection between the 4.0 industrial revolution and the education sector? 4.0 industrial revolution indirectly demands the world of education improves. With the characteristics of the workforce in this era, of course, it has an effect on the changing types of work available. There are many jobs that disappear because they are no longer needed. Changing the type of work, of course, requires a variety of new skills that must be possessed by graduates of Higher Education. According to the World Economic Forum (2015) in 2020 there were ten types of skills relevant to the industrial revolution era 4.0, namely: (i) complex problem solving, (ii) coordinating with others, (iii) people management, (iv) critical thinking, (v) negotiation, (vi) quality control, (vii) service orientation, (viii) judgment and decision making, (ix) active learning, and (x) creativity.

In the industrial revolution era 4.0, the challenge of preparing graduates with just a variety of skills is not enough. Another important thing is to prepare human resources, especially lecturers. Differences in the generation between lecturers and students are considered as the main factors causing educational failure. Why is that? The majority of lecturers who teach in tertiary institutions come from generation $\mathrm{X}$, and $\mathrm{Y}$ have different characteristics from students who are now inhabited by generation $\mathrm{Z}$. Generation $\mathrm{Z}$ is closely related to digital devices that do not match the learning methods offered by lecturers. The use of conventional methods in learning for $\mathrm{Z}$ generation is something that is not interesting. That gap or difference is the biggest single problem faced by the campus world today [1]. Thus, it is necessary to develop lecturer competencies on an ongoing basis throughout the campus. This development aims to make the quality of learning and college graduates in accordance with the demands of the world of work in the era of industrial revolution 4.0.

\section{Research methods}

The research method used is library research, which explains in theory about the author's arguments regarding the readiness of lecturer competencies in universities in the current and future. This article highlights some of the lecturer competencies that must be mastered immediately, among others: (i) educational competence, (ii) competence in research, (iii) technological commercialization competencies, (iv) competence in future strategies, (v) competence counselor, (vi) competence in globalization, and (vii) joint competence.

\section{Results and discussion}

With the onset of the 4.0 industrial revolution era, it certainly had an impact on the field of education, especially higher education. Every campus must improve and have the readiness 
to change the learning paradigm that has been used so far. This millennial era learning is no longer limited to the divisions of classrooms but is already unlimited. The use of digital technology and social media is considered more in line with the current learning model. Learning is already possible in each student's home by utilizing technology. The thing that should be noted in the implementation of education in higher education is to provide adequate facilities and infrastructure. It has become the thing that must be provided by the college is adequate internet access in the campus environment. Even in the future, universities must migrate to e-campus by providing e-laboratories, e-services, electronic libraries or e-libraries, online learning or e-learning, online tutors, or e-lecturers until the electronic thesis preparation and revision or e-thesis [2]. There are three main fundamental roles in higher education, namely teaching, research, and service. When compared with Indonesia, the role of the tertiary institution is known as the Tridharma Perguruan Tinggi, namely teaching, research, and community service. However, until now, the majority of universities in Indonesia have not provided the best service for students. Supporting aspects on campus are still conventional and seem to "make it difficult" for students. How should higher education place itself in the era of industrial revolution 4.0? From the illustration above, universities must immediately change and adapt to the current era. There are several things that are important points in the transformation of the higher education system, namely: (i) future curriculum, (ii) professional teaching staff, (iii) initial exposure in the workplace, (iv) new agreement on lifelong learning, and (v) openness to educational innovation [3].

Lecturer Competence in the Era of Industrial Revolution 4.0 Before reviewing the competence of lecturers in this era, it is a good idea to explore the definition of the word competence. When compared with English, the word competence refers to the word's competence and competency. On the other hand, the word competency is also difficult to distinguish from several other words that have almost the same meaning, such as skills or abilities. Nevertheless, in the world of education today, the term that is popularly used is the learning outcome. According to [4], the lack of a clear definition between the words competence and competency causes these two words to be used differently in various aspects or fields and several countries. Based on its use in various countries, the two words can be distinguished. Competence is a term that is often used in the United Kingdom, while competency is a concept that is influenced by the way people think in the United States. Simply put, competences refer to the output needed in minimum standards specifically while competencies are inputs that a person brings into his work that produce good performance [5].

There are various types of competencies for teachers and lecturers that were raised by experts. One of them is the United Nations Educational, Scientific, and Cultural Organization (UNESCO), which calls for important competencies in the 21 st century. The competence for teachers and lecturers referred to by UNESCO is the competence of Information Communication and Technology (ICT). There are three approaches used in developing this ICT competency, namely: (i) technology literacy, (ii) knowledge deepening, and (iii) knowledge creation. If referring to Law Number 14 concerning Teachers and Lecturers in 2005, there are several competencies required for this lecturer. These various competencies must be fulfilled so that they can be regarded as professional teachers. With the fulfillment of these various competencies, a teacher can obtain a certificate as an educator. The competencies in question are pedagogic, professional, social, and personality competencies. In addition to these main competencies, a lecturer is also required to have various other supporting skills, such as competency, innovation, creativity, anticipation, experimentation, open-mindedness, and networking or networking [6]. Given the increasingly fierce competition in the industrial revolution era 4.0, the teaching profession must also be developed along with the pace of the times. For 
this reason, some lecturer competencies in the era of education 4.0 must be mastered, namely: (i) educational competence; basic abilities in this era that refer to the internet of things, (ii) competence in research; lecturer competency in the field of research and its direction going forward, (iii) competence for technological commercialization; competence in the process of commercializing the results of research and innovation, (iv) competence in globalization, (v) competence counsellor, (vi) strategic competence in future, and (vii) Joint competence

Lecturer competencies in this era cannot be equated with previous era competencies. Today, the presence of the Internet of Things (IoT) has become a part of human life. Thus, the ability to understand and use a variety of IoT-based equipment for education and pursuit must be mastered. IoT is a condition that allows humans or objects to be able to connect with who only, in where only, and When only IoT is a technology relatively new emerging to facilitate between real and virtual objects [7]

IoT in everyday life is very commonplace we meet. Some examples of IoT in question are online transportation (Gojek, Grab), e-commerce, airplane, and train ticket bookings online, live streaming, and etc. Infield health even IoT too already start applied. With using health equipment connected to the internet, a doctor can check blood pressure and some medical tests from his patient. In the field of education, a real example of the application of IoT is the application of learning in a manner electronic or e-learning, education distance far (distance learning), library digital (digital library), e-commerce for campus MSMEs, and others. For this reason, the competence of lecturers must continue to be upgraded by familiarizing themselves with the various devices connected with IoT in the learning process. In English language learning, for example, IOT also been used by several lecturers' premises nusing a sound sensor and visual sensors in detecting faulty pronunciation or pronunciation [8]. Learning with this interactive system is assessed to increase students' enthusiasm and motivation in learning languages.

\section{Competence in research}

One of the duties of lecturers, in addition to teaching and carrying out community service, is research. In carrying out research assignments, of course, lecturers must master various skills in research. There is not much literature that presents definitions of skills in research. However, Badke revealed that research skills are skills to recognize problems, identify the right sources of information to respond to problems, assess quality from relevance information that found, and use information in a manner effective for resolving the problem [9].

So, what are the skills in this research? According to Easterby-Smith quoted [5], there is some category that should be owned by researcher that effective, that are: (i) capabilities and knowledge that are as diverse as knowledge in the disciplines owned and related to their sub-disciplines, (ii) ability to use research methods, (iii) ability and knowledge about methods of data collection, (iv) rhetorical skills in compiling logical and persuasive arguments, (v) management and time utilization, (vi) capability to work in groups, (vii) writing and presentation skills, (vii) computer skills, and (ix) ability to continually find solutions to problems. In the era revolution industry, competence in research too penetrates the realm that more large. Every lecturer is expected to be able to build networks in developing science and research. In addition, lecturers must also be skilled and dexterous in looking at the trends in world research in order to be able to determine the direction of research and obtain research assistance/grants from outside countries. 


\subsection{Competence for technological commercialization}

Higher education can be said to be the center of innovation in science and technology. However, in its implementation, many campuses experience obstacles in commercializing innovation that is. The commercialization of new technologies found by lecturers or campuses has a significant impact on sustainable economic growth, science \& technology, campus, and industry. However, the majority of commercialization projects in Indonesia cannot achieve satisfactory results because of the risks that are too large, and which are not certainly.

According to Jolly quoted [10] the commercialization of technology refers to its meaning in a process that starts with techno-market insights and ends with a sustainable function of products needed by the market. Furthermore, Block and McMillan outlined that there are several important things so that the commercialization process can be successful, namely: (i) completion of concept and product testing, (ii) prototype completion, (iii) first financing, (iv) completion of factory tests first, (v) market testing, (vi) producing start-ups, and (vii) seeing the first competitive reaction.

In the future, it is expected that lecturers have competence in commercializing technology off-campus even abroad. One of them is the result of collaboration-based research with students or innovation results findings that have value sell in society. Results innovation and research should not only be used as material for reports that accumulate in warehouses but also must be commercialized to the public to obtain profit.

\subsection{Competence for technological commercialization}

Table 1. Competence and description

\begin{tabular}{|c|c|}
\hline Category & Competency description \\
\hline ICT competencies & $\begin{array}{l}\text { i. The ability to use ICT according to business needs } \\
\text { ii. Understand the strengths and weaknesses of different sources of } \\
\text { information } \\
\text { iii. The ability to find quality information with help ICT } \\
\text { iv. The ability to identify problems with ICT }\end{array}$ \\
\hline $\begin{array}{l}\text { Project leadership and } \\
\text { management competencies }\end{array}$ & $\begin{array}{l}\text { Ability to regulate one's abilities own } \\
\text { ii. The ability to use or utilize people's knowledge and exper- } \\
\text { tise other } \\
\text { iii. Ability to be the responsible answer } \\
\text { iv. Ability to make decision }\end{array}$ \\
\hline $\begin{array}{l}\text { Knowledge management } \\
\text { and collaboration } \\
\text { competencies }\end{array}$ & $\begin{array}{l}\text { i. Ability to build relationships nationally and internationally and } \\
\text { network-level professionall } \\
\text { ii. The ability to share information and knowledge on team } \\
\text { members (group) } \\
\text { iii. Ability to resolution problems collaborative } \\
\text { iv. Ability to understand perspective, needs, and the value of } \\
\text { people other }\end{array}$ \\
\hline $\begin{array}{l}\text { Communication } \\
\text { competence }\end{array}$ & $\begin{array}{l}\text { The ability to communicate sensitively is related to personal and } \\
\text { cultural issues } \\
\text { ii. The ability to listen to others and consider suggestions and } \\
\text { thoughts they } \\
\text { iii. Ability to communicate clearly and articulate } \\
\text { iv. The ability to focus on essential points in communication }\end{array}$ \\
\hline
\end{tabular}

Table 1 . continue to the next page 
Table 1. Competence and description (Continue)

\begin{tabular}{|l|l|}
\hline \multicolumn{1}{|c|}{ Category } & \multicolumn{1}{|c|}{ Competency description } \\
\hline Cultural competency & i. $\begin{array}{l}\text { Foreign language skills (English, Mandarin, Arab) } \\
\text { ii. Understanding the influence and cultural implications in the } \\
\text { world of work }\end{array}$ \\
& $\begin{array}{l}\text { iii. Ability to adjust to different cultures } \\
\text { iv. Ability to evaluate perspectives, practices, and products } \\
\text { from multiple perspectives cultural }\end{array}$ \\
\hline
\end{tabular}

There are several competencies that must be implemented in the school and college curriculum. According to Pawlowski and Holtkamp there are seven global competencies, namely: (i) general or generic competence, (ii) IS or Information System competencies, (iii) ICT competencies, (iv) project management and leadership competencies, (v) knowledge and collaboration management competencies, (vi) communication competencies, and (vii) intercultural competencies. Furthermore, Sten (2012) describes the competency of each of the above competencies. In summary, it can be seen in the following Table 1.

\subsection{Counsellor competence}

Challenges in the field of education are not easy. In the future, many students or students experience depression and excessive mental stress. The depression is not caused by problems in receive learning, but more many related to problem personal, the more complex. Profession lecturer not only struggling with process learning only but expanding to the realm of counseling. A lecturer should able to be a counsellor for para the student to giving motivation, enthusiasm, encouragement, and advice for their problems facing.

Urbani describes 18 skills in the counselor's competence that are categorized into three groups, namely exploring, understanding, and acting [11]. Exploring groups consist of eye contact, body language, tone of voice, questions, paraphrases, and summarizing. The stage of understanding or understanding is divided into several points, namely the ability to identify content and feelings, self-disclosure, concrete and real expressions, urgency, and confrontation. Finally, the acting stage is divided into: (i) the ability to make decisions, (ii) make alternative choices, (iii) make expectations, (iv) get approval, (v) make an appointment, and (vi) review all actions to determine results.

\subsection{Competence in future strategies}

At present, various challenges cannot be predicted from various aspects as a result of globalization and the pace of technological development. The inability of humans to guess future events can at least be anticipated by the ability of each individual to predict the possibilities that will occur. Lecturers as spears in higher education must be able to predict and predict the various possibilities that occur in the world of education [12].

Following up on this issue, the lecturer must continue to work on developing the network and its links throughout the world. This network can be built through various academic activities such as (i) establishing collaboration in research (collaborative research with foreign campuses), (ii) joint lecturer programs, (iii) exchange employee campus, etc. With many follow, works the same with various campuses around the world will have a positive impact on campus development in the country. At least, the pace of campus movement in Indonesia is not far behind global issues in world education. 


\subsection{Joint Competence}

Some things about joint competence, for example, in the field of joint-lecture, joint research, joint publication, joint lab, staff mobility, and rotation, understand the direction of SDG's and industry, and so forth. Based on Government Regulation Number: 30 of 1990, Article 122 paragraph (2), the form of cooperation between universities/institutions includes the following:

i. Exchange of lecturers and students;

ii. Shared use of human resources;

iii. Shared use of learning facilities and infrastructure;

iv. Issuance of joint scientific work;

v. Organizing scientific activities such as seminars and joint research;

vi. Other forms deemed necessary.

vii. Examples of cooperation in Higher Education are taken from Ristedikti students:

\section{Conclusion}

The challenge is increasingly massive for educators in the current era of industrial revolution 4.0. The onslaught of digital technology will inevitably affect the world of education. The many types of jobs lost and replaced with new types of work require college graduates to master various competencies accordingly with characteristics revolution industry 4.0. In the meet aim that, then position lecturer as the spearhead of higher education is required to develop their competencies too. In-Law Number 14 of 2005 concerning Teachers and Lecturers, various competencies must be mastered by teachers and lecturers. However, along with the flow of globalization and the advancement of digital technology, several competencies need to be mastered by lecturers. Some of the competencies in question are educational competence, competence in research, competence for technological commercialization, competence in globa $\neg$ lization, counselor competence, competence in future strategies and joint competence.

\section{References}

1. C. Jones, B. Shao, The Net Generation and Digital Natives : Implications for Higher Education. UK: Higher Education Academy, York. (2011). http://oro.open.ac.uk/30014/

2. M.B. Djatmiko, Changes in Higher Education HR in the Era of Industrial Revolution 4.0. [Presentation], Jakarta: Gunadharma University (2018). [in Bahasa Indonesia]. https://seminar.gunadarma.ac.id/wp-content/uploads/2018/09/APPERTI-26September-2019.pdf

3. World Economic Forum (WEF). New Vision for Education: Unlocking The Potential of Technology, WEF, (2015). p. 1-32.

http://www3.weforum.org/docs/WEFUSA_NewVisionforEducation_Report2015.pdf

4. S. Grant, R. Young, International Journal of IT Standards and Standardization Research 8,2:29-44(2010). https://www.simongrant.org/pubs/JITSR/GrantYoung2010.html

5. T. Stén, Assessing Globalization Competences in the Information Systems DomainInstruments and Methods, [Research Report], Finland: University of Jyvaskyla, (2012), p. 36. https://www.semanticscholar.org/paper/Assessing-GlobalizationCompetences-in-the-SystemsSt\%C3\%A9n/0bad77c1aa461bb117aefc3c55c11fff528594b8 
6. N. Alis, W.M.W. Jaafar, A.F.M. Ayub, MATEC Web of Conferences, 150,5072:18(2018). https://doi.org/10.1051/matecconf/201815005072

7. M.B. Abbasy, E.V. Quesada, Int. J. Inf. Educ. Technol., 7(12):914-920(2017). http://www.ijiet.org/vol7/995-T49.pdf

8. M.A. Bakri, JREC: Journal of Electrical and Electronic, 4(1):18-23(2016). http://www.insightsociety.org/ojaseit/index.php/ijaseit/article/view/5043

9. A. Garg, M. Madhulika, D. Passey, Research Skills Future in Education: Building Workforce Competence:Research Report 1: Do We Cultivate Research Skills?

Veracity versus Falsity. [Collaborative Research Report], UK: Center for Technology Enhanced Learning and Lancaster University (2018). https://eprints.lancs.ac.uk/id/eprint/89496/

10. K. Harto. Tatsqif: Jurnal Pemikiran dan Penelitian Pendidikan, 16(1):1-15, (2018). [In Bahasa Indonesia]. https://journal.uinmataram.ac.id/index.php/tatsqif/article/download/159/83

11. World Economic Forum (WEF). Realizing Human Potential in The Fourth Industrial Revolution: An Agenda for Leaders to Shape the Future of Education, Gender and Work. Geneva: WEF(2017). https://www.weforum.org/whitepapers/realizing-humanpotential-in-the-fourth-industrial-revolution

12. A. Leone, I. Aquila, C. Vicinanza, C. Iaconetti, A. Bochicchio S. Ottolenghi, et al., Cardiovascular Research, 93,1:S46-S51(2012).

https://academic.oup.com/cardiovascres/article/93/suppl_1/S46/332256 